\title{
PROGRAM SEKOLAH DASAR BERSIH DAN SEHAT DI SD NEGERI 43 PEKANBARU
}

\author{
Susi Susanti ${ }^{1)}$ \\ Isjoni $^{2)}$ \\ Daeng Ayub Natuna ${ }^{3)}$ \\ ${ }^{1)}$ Post Graduate Student of Riau University \\ ${ }^{2)}$ Lecturer of Education Management Study Programme PPs University of Riau \\ ${ }^{3}$ Lecturer of Education Management Study Programme PPs University of Riau
}

\begin{abstract}
This study is a qualitative research that aims to determine how the implementation of the program an SD Clean Healthy (SDBS) in SD Negeri 43 Pekanbaru. This study focuses on the implementation of the program of Clean and Healthy SD (SDBS) in SD Negeri 43 Pekanbaru. Subfokus this study consisted of 1) How is the implementation of the primary school program a clean and healthy in SD Negeri 43 Pekanbaru, 2) How to efforts to implement school programs are clean and healthy at the SD Negeri 43 Pekanbaru, 3) How will the results of the program the school is clean and healthy (SDBS) SD Negeri 43 Pekanbaru. This research data collection through interviews, observation and documentation. The results showed that the subfokus beginning of primary school program a clean and healthy (SDBS) in SD Negeri 43 Pekanbaru already in the good category, subfokus efforts to implement primary school program a clean and healthy (SDBS) in SD Negeri 43 Pekanbaru already performing well, in exercising their success subfokus program clean and healthy primary school (SDBS) in SD Negeri 43 Pekanbaru also been performing well. It can be seen that for implementation of a Clean and Healthy Primary School (SDBS) students at SDN 43 Pekanbaru overall and subfokus aspects of research can be said is good because of the three subfokus everything is located in both categories.
\end{abstract}

Keywords: Program, Elementary School Clean and Healthy

\begin{abstract}
ABSTRAK: Penelitian ini merupakan penelitian kualitatif yang bertujuan untuk mengetahui bagaimana pelaksanaan program SD Bersih an Sehat (SDBS) di SD Negeri 43 Pekanbaru. Penelitian ini memfokuskan pada pelaksanaan program SD Bersih dan Sehat (SDBS) di SD Negeri 43 Pekanbaru. Subfokus penelitian ini terdiri dari 1) Bagaimana pelaksanaan program sekolah dasar bersih dan sehat di SD Negeri 43 Pekanbaru, 2) Bagaimana upaya pelaksanaan program sekolah bersih dan sehat di SD Negeri 43 Pekanbaru, 3) Bagaimana hasil dari program sekolah bersih dan sehat (SDBS) di SD Negeri 43 Pekanbaru. Pengumpulan data penelitian ini dilakukan dengan wawancara, observasi dan dokumentasi. Hasil penelitian menunjukkan bahwa pada subfokus awal pelaksanaan program sekolah dasar bersih dan sehat (SDBS) di SD Negeri 43 Pekanbaru sudah berada pada kategori baik, subfokus upaya pelaksanaan program sekolah dasar bersih dan sehat (SDBS) di SD Negeri 43 Pekanbaru sudah terlaksana dengan baik, pada subfokus keberhasilan pelakasanaan program sekolah dasar bersih dan sehat (SDBS) di SD Negeri 43 Pekanbaru juga sudah terlaksana dengan baik. Maka dapat diketahui bahwa untuk pelaksanaan program Sekolah Dasar Bersih dan Sehat (SDBS) siswa di SD Negeri 43 Pekanbaru secara keseluruhan dan aspek subfokus penelitian dapat dikatakan sudah baik karena dari tiga subfokus semuanya sudah berada pada kategori baik.
\end{abstract}

Kata kunci: Program, Sekolah Dasar Bersih dan Sehat 


\section{LATAR BELAKANG}

Promosi Kesehatan di institusi pendidikan (Health Promoting School) yang dicanangkan oleh Organisasi Kesehatan Dunia (WHO, 1995) menggunakan model holistik yang meliputi hubungan antar aspek fisik, mental, sosial, dan lingkungan. Konsep ini melibatkan keluarga dengan mendorong partisipasinya dalam meningkatkan pengetahuan dan keterampilan peserta didik (mulai dari usia dini) tentang kesehatan serta menunjukkan makna lingkungan sebagai penyumbang kesehatan anak seperti kondisi fisik sekolah, sanitasi air bersih, dan lingkungan bermain.

Visi pembangunan kesehatan Indonesia saat ini adalah Indonesia Sehat 2010, yang ditandai dengan penduduknya hidup dalam lingkungan dan perilaku hidup sehat. Visi ini dijabarkan menjadi masyarakat yang mandiri untuk hidup sehat, dengan mengajak serta memotivasi masyarakat dan penyelenggara pelayanan kesehatan untuk mengubah pola pikir dari sudut pandang sakit menjadi sudut pandang sehat; dan jabaran ini disebut dengan Paradigma Sehat. Perilaku Hidup Bersih dan Sehat (PHBS) merupakan perwujudan riil paradigma sehat dalam budaya hidup perorangan, keluarga dan masyarakat yang berorientasi sehat, bertujuan untuk meningkatkan, memelihara dan melindungi kesehatannya (Depkes RI, 2006).

SD Negeri 43 Pekanbaru sudah melaksanakan program sekolah dasar bersih dan sehat tersebut, tetapi pelaksanaannya belum berjalan secara optimal. Hasil wawancara awal peneliti dengan Ketua pelaksana program Sekolah Dasar Bersih dan Sehat (SDBS) pada tanggal 15 Januari 2016 peneliti memperoleh informasi bahwa belum optimalnya SD Negeri 43 Pekanbaru mengimplementasi kan program Sekolah dasar bersih dan sehat ini adalah disebabkan oleh beberapa faktor yaitu: 1). Masih kurangnya kesadaran para warga sekolah mengenai PHBS (Perilaku Hidup Bersih dan Sehat), 2). Masih kurangnya sarana dan prasarana dalam mendukung program sekolah dasar bersih dan sehat di SD Negeri 43 Pekanbaru dengan dibuktikan belum adanya ruangan UKS di SD Negeri 43 Pekanbaru tersebut, 3) Masih banyak warga sekolah yang membuang sampah sembarangan, 4) Masih banyak siswa yang belanja sembarangan.

\section{METODE PENELITIAN}

Sesuai dengan rumusan masalah, maka tujuan penelitian untuk mengungkap, menganalisa secara jelas dan cermat terhadap beberapa hal, yaitu:

1. Untuk mengetahui bagaimana awal pelaksanaan program sekolah dasar bersih dan sehat di SD Negeri 43 Pekanbaru

2. Untuk mengetahui bagaimana upaya pelaksanaan program sekolah dasar bersih dan sehat di SD Negeri 43 Pekanbaru

3. Untuk mengetahui hasil dari program sekolah bersih dan sehat di SD Negeri 43 Pekanbaru

Penelitian ini dilaksanakan di SD Negeri 43 Kota Pekanbaru Propinsi Riau. Pengambilan data dilaksanakan selama 3 bulan berturut-turut pada awal bulan Maret sampai dengan akhir bulan Mei 2016.

\section{Jenis Data}

Penelitian dilaksanakan menggunakan data primer, yaitu data yang diperoleh seorang peneliti dari sumber utama secara langsung. Data ini hanya digunakan bagi peneliti saja (data yang tidak dipublikasikan), dan tidak dapat digunakan oleh peneliti yang lain karena tujuan penelitiannya berbeda.

\section{Sumber Data}

Dalam penelitian ini data dan sumber data yang diambil adalah melalui Kepala Sekolah SD Negeri 43 Pekanbaru, Wakil Kepala Sekolah, Ketua Program SDBS, Guru, dan Siswa SD Negeri 43 Pekanbaru.

Terdapat beberapa teknik pengumpulan data, tetapi dalam penelitian ini yang digunakan adalah teknik wawancara, observasi dan dokumentasi. Data diperoleh dari: Kepala Sekolah SD Negeri 43 Pekanbaru, Wakil 
Kepala Sekolah, Ketua Pelaksana Program SDBS, Guru, dan Siswa SD Negeri 43 Pekanbaru.

Prosedur dalam memperoleh data melalui langkah-langkah sebagai berikut:

a. Menjumpai informan utama, yaitu Kepala Sekolah SD Negeri 43 Pekanbaru, Wakil Kepala Sekolah, Ketua Pelaksana Program SDBS, Guru, dan Siswa SD Negeri 43 Pekanbaru.

b. Mempersiapkan wawancara berupa pertanyaan-pertanyaan yang telah disusun secara terstruktur

c. Mempersiapkan dokumentasi dan hasil pengamatan penelitian

Selanjutnya berdasarkan jenis penelitian ini yaitu penelitian kualitatif, maka analisis data dilakukan saat pelaksanaan penelitian, baik langsung dilakukan pada saat pengambilan data maupun setelah data terkumpul memakai teknik yang dikemukakan oleh Jhon W Creswell dalam Diah.

\section{HASIL DAN PEMBAHASAN 1. Latar Penelitian}

SD Negeri 43 Pekanbaru berdiri pada tahun 1977. Terletak di Jalan Banda Aceh No. 37 Tangkerang Utara Kecamatan Bukitraya. Pada awal berdirinya SD Negeri 43, dahulunya bernama SD 001 Siak Hulu kemudian tahun 1984 dipecah menjadi SD Negeri 20, seterusnya menjadi SD Negeri 023 Bukitraya dan sekarang bernama SD Negeri 43 Pekanbaru. SD Negeri 43 Pekanbaru dipimpin oleh Bapak H. Harun Muhammad, BA. Dengan jumlah tenaga pendidik dan tenaga kependidikan 19 orang. Jumlah pendidik dan tenaga kependidikan yang berperan dalam kegiatan pendidikan di SD Negeri 43 Pekanbaru saat ini adalah sebagai berikut ; (a) Kepala sekolah 1 orang, (b) Guru kelas (1-6) 12 orang, (c) Guru mata pelajaran Agama Islam 2 orang, (d) Guru mata pelajaran Penjas Orkes 2 orang, (e) Tenaga administrasi sekolah 1 orang, dan (f) Penjaga sekolah 1 orang. Jumlah peserta didik kelas 1-6 Tahun Pelajaran 2015/2016 berjumlah 384 orang.
Siswa kelas 1 berjumlah 78 orang, siswa kelas 2 berjumlah 72 orang, siswa kelas 3 berjumlah 50 orang, siswa kelas 4 berjumlah 80 orang, kelas 5 berjumlah 64 orang, dan siswa kelas 6

\section{Temuan Penelitian}

- Subfokus 1 Awal Pelaksanaan Program Sekolah Bersih dan Sehat di SD Negeri 43 Pekanbaru

Dari temuan penelitian baik wawancara, observasi dan dokumentasi kegiatan sekolah pada program SD Bersih dan Sehat yang diperoleh oleh peneliti dari Kepala Sekolah, Wakil Kepala sekolah, guru dan Komite sekolah dapat terlihat bahwa perencanaan program SD Bersih dan Sehat di SD Negeri 43 Pekanbaru telah berjalan dengan baik. Semua unsur komponen sekolah dan masyarakat telah dilibatkan dan sama-sama mendukung perencanaan pelaksanaan program SD Bersih dan Sehat di SD Negeri 43 Pekanbaru tersebut dengan baik.

- Subfokus 2 Upaya Pelaksanaan Program Sekolah Dasar Bersih dan Sehat (SDBS) di SD Negeri 43 Pekanbaru

Dalam upaya terlaksananya program SD Bersih dan Sehat di SD Negeri 43 Pekanbaru, pihak sekolah terus melaksanakan kerjasama dengan pihak terkait guna terealisasinya program SD Bersih dan Sehat tersebut sehingga tujuan yang ditetapkan dapat tercapai. Bentuk-bentuk kerjasama yang dilakukan yakni kerjasama dengan puskesmas terdekat untuk selalu menjaga kebersihan dan kesehaan warga sekolah di SD Negeri 43 Pekanbaru dan sekaligus lingkungannya.

- Subfokus 3 Keberhasil Pelaksanaan Program Sekolah Dasar Bersih dan Sehat (SDBS) di SD Negeri 43 Pekanbaru.

Dari temuan penelitian yang telah dilakukan oleh peneliti melalui pedoman wawancara, observasi dan dokumentasi melalui para informan di SD Negeri 43 Pekanbaru bahwa upaya dalam pelaksanaan program SD Bersih dan Sehat sudah 
berjalan dengan baik. Semua komponen yang terlibat telah melaksanakan tugas dan tanggungjawabnya dengan baik sehingga pelaksanaan program SD Bersih dan Sehat tersebut dapat terlaksana dengan baik.

\section{Pembahasan}

Penilaian penelitian ini dilakukan dengan triangulasi. Dari hasil paparan data dan hasil temuan maka, dapat disimpulkan pembahasan hasil temuan penelitian berdasarkan subfokus penelitian berikut ini untuk lebih jelasnya dapat dilihat pada tabel berikut:

Tabel 4.5 Rekapitulasi Pembahasan Hasil Penelitian

\begin{tabular}{|c|c|c|c|}
\hline No & Subfokus & Indikator & $\begin{array}{c}\text { Hasil/Kriteria } \\
\text { Pencapaian }\end{array}$ \\
\hline 1. & $\begin{array}{l}\text { Perencanaan } \\
\text { pelaksanaan } \\
\text { program SDBS }\end{array}$ & $\begin{array}{l}\checkmark \text { Penyusunan } \\
\text { SDBS } \\
\checkmark \text { Susunan pelaksana } \\
\text { program SDBS } \\
\checkmark \text { Upaya dalam } \\
\text { membangun kemitraan } \\
\text { terhadap warga sekolah }\end{array}$ & $\begin{array}{l}\checkmark \text { Semua indikator sudah } \\
\text { terlaksana dengan baik. }\end{array}$ \\
\hline 2. & $\begin{array}{l}\text { Upaya } \\
\text { pelaksanaan } \\
\text { program SDBS }\end{array}$ & $\begin{array}{l}\checkmark \text { Sosialisasi pelaksanaan } \\
\text { program SDBS } \\
\checkmark \text { Upaya } \\
\text { pelaksanaan } \\
\quad \text { SDBS }\end{array}$ & $\begin{array}{l}\checkmark \text { Dari } 2 \text { indikator pada } \\
\text { subfokus } 2 \text { juga sudah } \\
\text { dilaksanakan dengan } \\
\text { baik. }\end{array}$ \\
\hline 3. & $\begin{array}{l}\text { Keberhasilan } \\
\text { pelaksanaan } \\
\text { program SDBS }\end{array}$ & \begin{tabular}{rlr}
$\checkmark$ & \multicolumn{2}{l}{ Hasil akhir pelaksanaan } \\
& program SDBS \\
$\checkmark$ & Hambatan yang \\
& ditemui dalam \\
& pelaksanaan program \\
& SDBS \\
$\checkmark$ & Evaluasi pelaksanaan \\
& program SDBS
\end{tabular} & $\begin{array}{llr} & \text { Dari 3 indikator pada } \\
\text { subfokus } & 3 & \text { ini } \\
\text { semuanya } & \text { sudah } \\
\text { terlaksana } & \text { dengan } \\
\text { baik. } & \\
\end{array}$ \\
\hline
\end{tabular}

\section{SIMPULAN DAN SARAN}

Hasil penelitian ini dilakukan secara kualitatif, berdasarkan data yang diperoleh dari wawancara, observasi dan dokumentasi tentang program SDBS di SD Negeri 43 Pekanbaru, dapat disimpulkan bahwa:

1. Dalam tahapan perencanaan program SD Bersih dan Sehat di SD Negeri 43 Pekanbaru, peran Kepala Sekolah, Wakil Kepala Sekolah, guru, Ketua tim SDBS dan komite sekolah sangatlah penting. Kerjasama yang baik dalam penyusunan program dan kegiatan-kegiatan yang mendukung program SD Bersih dan Sehat inilah yang menjadikan perencanaan tersebut matang dan mampu dilaksanakan dengan baik di sekolah. Perencanaan dilakukan dengan mengacu pada tujuan program SD Bersih dan Sehat yang akan dicapai dan dapat dilaksanakan dengan baik.

2. Dalam tahap pelaksanaan, kerjasama yang baik dari kepala sekolah selaku pimpinan, guru, komite sekolah dan ketua tim SDBS selaku pembina kegiatan dalam program SD Bersih dan Sehat, siswa selaku pelaksana harian dan komite sebagai faktor pendukung dan pengawas menjadikan program SDBS di SD Negeri 43 Pekanbaru terlaksana 
secara maksimal dan mencapai tujuan yang diinginkan. Pelaksanaan program SDBS ini dilakukan selalu mengacu pada perencanaan yang sebelumnya telah disepakati bersama sehingga pelaksanaan terprogram dengan baik dan berjalan sesuai dengan tujuan yang akan dicapai. Pelaksanaan program SD Bersih dan Sehat dilakukan dengan kegiatankegiatan yang telah disusun,sehingga kesuksesan kegiatan yang dilaksanakan menjadi cerminan kesuksesan pelaksanaan program SD Bersih dan Sehat di SD Negeri 43 Pekanbaru.

3. Dilihat dari hasil pelaksanaan program SD Bersih dan Sehat di SD Negeri 43 Pekanbaru tercermin bahwa keberhasilan pelaksanaan tersebut telah mencapai tujuan yang diinginkan. Dari tahun 2014 sampai sekarang selalu menunjukkan peningkatan ke arah yang lebih baik, program SD Bersih dan Sehat di SD Negeri 43 Pekanbaru menjadi teladan bagi sekolah lain dan diharap mampunantinya menjadi sekolah yang sudah bersih dan sehat dan sudah menerapkan PHBS.

Dari hasil temuan penelitian dan paparan simpulan di atas, maka peneliti dapat mengemukakan saran sebagai berikut:

1. Melihat keberhasilan yang telah diterapkan oleh SD Negeri 43 Pekanbaru dalam melaksanakan program SD Bersih dan Sehat di sekolah, sebaiknya sekolah-sekolah lain juga ikut menerapkan program SDBS dengan kegiatan-kegiatan pendukung yang dilakukan oleh SD Negeri 43 Pekanbaru.

2. Dalam usaha menerapkan program SD Bersih dan Sehat di sekolah, bukan hanya tugas Kepala sekolah dan guru saja tetapi merupakan tugas seluruh warga sekolah. dengan kerjasama yang baik programprogram yang direncanakan akan berjalan dengan baik dan mencapai hasil yang baik pula.

3. Upaya perencanaan dan pelaksanaan program SD Bersih dan Sehat di SD Negeri 43 Pekanbaru diharapak memberikan bimbingan kepada sekolah yang ada di Kota Pekanbaru yang ingin melaksanakan program SDBS di sekolahnya sehingga menjadi program yang terus berkelanjutan.

\section{DAFTAR PUSTAKA}

Ahmadi, 2001. Pedoman dalam mengajar sesuai kurikulum. Pebieta, Bandung,

Creswell, Jhon W, 2011. "Penelitian Kualitatif dalam bidang pendidikan.Alih Bahasa Muhammad Diah Z, Pekanbaru, UMRI Press.

Depkes RI, 2008 , Pedoman Pengelolaan Promosi Kesehatan Dalam Pencapaian Perilaku Hidup Bersih Dan Sehat, Depkes RI, Jakarta

Depkes RI, 2009, Pedoman Pelaksanaan Promosi Kesehatan Di Daerah, Depkes RI, Jakarta.

Depkes RI , 2008, Panduan Promkes Dalam Pencapaian Perilaku Hidup Bersih Dan Sehat Tatanan Rumah Tangga, Depkes RI, Jakarta.

Depkes RI, 2009, Pembinaan Perilaku Hidup Bersih Dan Sehat Di Berbagai Tatanan, Depkes RI, Jakarta.

Depkes RI, 2006, Panduan Pembinaan Perilaku Hidup Bersih dan Sehat di Rumah Tangga melalui Tim Penggerak PKK, Jakarta.

Fattah, Nanang. 2012. Analisis Kebijakan Pendidikan. PT.Remaja Rosdakarya. Bandung

Hasbullah, 2005. Promosi Kesehatan Siswa Sekolah, Graha Ilmu, Yogyakarta

Hamalik, Oemar. 2006. Manajemen Pengembangan Kurikulum. PT. Remaja Rosdakarya. Bandung.

Hamruni, 2011. Strategi Belajar Mengajar, CV. Pustaka Setia, Bandung.

Imron, Ali. 2012. Manajemen Pendidikan. Surabaya: UNM Press, Malang Ismoyowati, 2007. Indahnya Pola Hidup Sehat, PT. Bumi Aksara, Bandung

Kementerian Kesehatan Republik Indonesia, 2011. PHBS di sekolah, Kemeterian Kesehatan RI, Jakarta. 
Kementerian Pendidikan dan Kebudayaan Direktorat Jenderal Pendidikan Dasar, Direktorat Pendidikan Sekolah Dasar, 2014. Tentang Panduan Pelaksanaan Sekolah Bersih dan Sehat (SDBS). Jakarta.

Notoatmodjo Soekidjo 2010, Metodologi Penelitian Kesehatan, Rineka Cipta, Jakarta.

Nurdin dan Usman, 2004. Implementasi sebagai Evaluasi. PT. Bumi Aksara. Jakarta.

Sugijanto, 2005. Budaya Perilaku Hidup Bersih dan Sehat. Rineka Cipta, Bandung. Sya'roni, 2007. Pedoman Pelaksanaan Promosi Kesehatan Di Sekolah. Rineka Cipta. Jakarta
Purwanto dan Sulistiyastuti, 2012. Konsep Dasar Kbijakan Publik. Rineka Cipta. Jakarta.

Purwoko, 2001. Kebijakan Publik, Membangun Pelayanan Publik Yang responsif, Hakim Publishing, Bandung.

Undang-Undang Republik Indonesia Nomor 36 tahun 2009 tentang kesehatan, 2011. Anfaka Perdana, Surabaya.

Dunn, William N,2000. Pengantar Analisis Kebijakan Publik, Jogjakarta, Gajah Mada University Press.

Wayne Parsons, 2005. Poblic Policy, Pengantar Teori Praktik Analisis Kebijakan. Kencana. Jakarta. 